\title{
Radiation therapy for the solitary plasmacytoma
}

\author{
Soliter plazmasitom'un radyoterapi ile tedavisi
}

\author{
Esengül Koçak1,2, Giorgio Ballerini ${ }^{1}$, Abderrahim Zouhair¹, Mahmut Özşahin ${ }^{1}$ \\ ${ }^{1}$ Departments of Radiation Oncology, University of Lausanne Medical Center, Lausanne, Switzerland \\ ${ }^{2}$ Cerrahpaşa School of Medicine, University of Istanbul, Istanbul, Turkey
}

\begin{abstract}
Plasma-cell neoplasms are classically categorized into four groups as: multiple myeloma (MM), plasma-cell leukemias, solitary plasmacytomas (SP) of the bone (SPB), and extramedullary plasmacytomas (EMP). These tumors may be described as localized or diffuse in presentation. Localized plasma-cell neoplasms are rare, and include SP of the skeletal system, accounting for 2-5\% of all plasma-cell neoplasms, and EMP of soft tissue, accounting for approximately $3 \%$ of all such neoplasms. SP is defined as a solitary mass of neoplastic plasma cells either in the bone marrow or in various soft tissue sites. There appears to be a continuum in which SP often progresses to MM. The main treatment modality for SP is radiation therapy $(\mathrm{RT})$. However, there are no conclusive data in the literature on the optimal RT dose for SP. This review describes the interrelationship of plasma-cell neoplasms, and attempts to determine the minimal RT dose required to obtain local control. (Turk J Hematol 2010; 27: 57-61)
\end{abstract}

Key words: Solitary plasmacytoma, radiotherapy, multiple myeloma, management

Received: September 17, 2009

Accepted: March 3, 2010

\section{Özet}

Plazma hücre malignitesi klasik olarak dört gruptur: multiple myelom (MM), plazma hücre lösemisi, kemik yerleşimli soliter plazmasitom (SPB) ve ekstrameduller yerleşimli plazmasitom (EMP). Lokalize plazma hücre malignitesini iskelet sistemi yerleşimli SP ve EMP oluşturur. Plazmasitoma birçok farklı şekilde tanımlanabilir. Çoğunlukla kemik iliğinde veya yumuşak dokuda plazma hücrelerinden oluşan bir kitle şeklinde görülür. Henüz, soliter plazmositomların MM'a dönüşümü arasindaki ilişki tam olarak tanımlanmamıştır. Soliter plazmositomlar, hem SPB hem de EMP için ana tedavi radyoterapidir. Ancak, SP için uygun tedavi dozu için ortak bir data yoktur. Lokal kontrol için optimal doz hastalığın yerine ve boyutuna bağlı olarak 30 ve 50 Gy arasında değişmektedir. Bu derlemede lokal kontrol için minimal RT dozu tanımlanmaya çalışılmıştır. (Turk J Hematol 2010; 27: 57-61)

Anahtar kelimeler: Soliter plazmasitom, radyoterapi, multipl miyelom, tedavi yaklaşımı 


\section{Introduction}

Plasma-cell neoplasms account for approximately 1-2\% of human malignancies, and occur at a rate of 3.5/100,000 per year. Plasmacytoma, a clonal neoplastic disorder of bone marrow originating from plasma cells, the last maturation stage of B lymphocytes, may appear as four different diseases: multiple myeloma (MM, systemic disease), plasma-cell leukemias, extramedullary plasmacytoma (EMP), and solitary plasmacytoma (SP) of bone (SPB). This review article assesses the management of SPs, as the treatment of MM is mainly with systemic chemotherapy, and the role of local radiotherapy (RT) is restricted for palliation of symptoms. A diagnosis of SP is made when all the following criteria are satisfied [1]: a histologically confirmed single lesion with negative skeletal imaging outside the primary site, normal bone marrow biopsy (less than 10\% monoclonal plasma cells), and no myeloma-related organ dysfunction. Men are affected more than women (male-to-female ratio 2:1) [2]. The median age at the diagnosis of SP ranges between 55 and 65 years, on average about 10 years younger than patients with MM. EMPs are less common than SPBs [2-4]. Laboratory signs of SP are usually related to the immunoglobulin production, if the secretory component is present.

Solitary plasmacytoma most commonly presents in bone (80\%). SPBs are most often found in the axial skeleton, usually the vertebrae and skull [2]. Patients usually present with bone pain, sometimes associated with neurologic compromise and/or pathologic fracture. Less commonly, SP presents in an EMP site (20\%), usually found in the head and neck, and most often in the nasal cavity and nasopharynx $[2,3,5,6]$. The histologic diagnosis of EMP can be difficult, and the main differential diagnosis is extranodal marginal zone lymphoma $[5,7]$.

\section{Diagnostic Work-Up}

Diagnostic work-up at the presentation includes history, physical examination, complete blood count, bone marrow biopsy, serum protein electrophoresis, evaluation of the urine for myeloma protein, and skeletal survey. The incidence of a monoclonal gammopathy (M-protein) is present in $30-75 \%$ of cases (especially for bone presentation, usually minimally elevated $[\operatorname{lgG}<5 \mathrm{~g} / \mathrm{L}, \lg A<20 \mathrm{~g} / \mathrm{L}]$, and urine monoclonal kappa or lambda $<1.0 \mathrm{~g} / 24 \mathrm{~h}$ ) [8-9]. Tsang et al. [4] observed the following myeloma protein levels in the blood of 46 patients with SP: normal 59\%, minimally elevated $28 \%$ and elevated $13 \%$.

Skeletal survey is preferred over bone scintigraphy because the latter is only $40-60 \%$ sensitive for detecting bone lesions since the osteoblastic response to bone destruction by myeloma is negligible. Approximately $25-50 \%$ of bone trabeculae must be destroyed with a bone defect to be visible on a plain radiography. Thus, computed tomography $(\mathrm{CT})$ is more sensitive for detecting the extent of bone destruction. Some patients with suspected SPB will be upstaged following magnetic resonance imaging (MRI) with the detection of multiple vertebral lesions or bone marrow disease, with lesions being darker or isointense on T1-weighted images and hyperintense on T2-weighted images and enhanced with contrast [10-11] or positivity on 18F-fluorodeoxyglucose positron emission tomography (FDG-PET) $[12,13]$.

\section{Management of Solitary Plasmacytoma}

Radiation therapy (RT) is the standard treatment for SP. Surgery is considered for bone instability, fracture, or when there is rapidly progressive neurologic deterioration such as spinal cord compression $[1,14]$. For patients treated with surgical excision, RT is still indicated to eradicate microscopic residual disease. Surgery alone without $\mathrm{RT}$ leads to an unacceptably high local recurrence rate [2]. A review of the recent literature for SPB indicated high local control rates with RT (79$91 \%$ ) but a modest overall survival of approximately $50 \%$ at 10 years. Özşahin et al. [2] reported local control was better with small tumors $(<4 \mathrm{~cm})$ in patients treated with RT; however, no difference was observed between bone and extramedullary $\mathrm{SP}$. This is because of a high progression rate to $\mathrm{MM}$, a finding consistently reported by many investigators [2,4,15-18]. Over $60 \%$ of patients with SPB will progress to myeloma, usually within two to four years after treatment. Özşahin et al. [2] showed that SP seemed to develop MM in two peaks. A first peak during the first three years post-treatment is probably due to undetected existing MM by an asymptomatic gross disease becoming more obvious; a second peak, corresponding to a real MM development of previously occult disease, is observed after 6-9 years. Therefore, it appears SPB may be an early form of MM. Vertebral disease has been reported to be a poor prognostic factor compared to other bony localization [2]. The presence of low level M-protein pre-radiation is very common, and by itself is not associated with a higher risk of progression to MM. Patients showing persistent M-protein levels for more than one year after RT are prone to progress to MM $[16,19]$.

The addition of adjuvant chemotherapy to RT is, theoretically, attractive in an attempt to eradicate subclinical disease to prevent the disease relapsing as myeloma. Only one randomized trial suggested a benefit with adjuvant melphalan and prednisone given for three years after RT compared to RT alone [20]. However, this was a small study and the concerns regarding prolonged use of alkylating agents on the bone marrow do not justify its routine use. This study concluded that combined radiochemotherapy seemed to increase remission and survival duration.

Targeting the mechanisms that control angiogenesis, which have an integral role in the pathophysiology of hematologic malignancies, could be an innovative therapeutic approach in the treatment of SP. Kumar et al. [19] reported high-grade angiogenesis in 64\% of tumors in their series of 25 SPB patients, and found that angiogenesis is highly correlated with progression to $\mathrm{MM}$. Therefore, antiangiogenic compounds such as thalidomide, vascular-endothelial growth factor or proteasome inhibitors may be promising in this disease.

For EMP, complete surgical excision may be curative for small lesions. However, most patients with larger lesions or with tumor location not amenable to complete excision should receive local RT, and postoperative RT is indicated for incompletely excised lesions. In contrast to bone localization, EMPs are well controlled with local radiation. Of all plasma-cell tumors, EMPs have the best prognosis [5]. Evidence of local involvement of adjacent bone and/or lymph nodes does not necessarily indicate systemic disease, or signify a worse prognosis [21]. Conversion to MM is less likely than in patients with SPB with the best result 
reported in patients receiving surgery and/or RT [2,5,21-24]. Moreover, a substantial proportion of patients are cured of their disease. Although the 10-year survival varies widely in the recent literature (range: 50-78\%), the two largest series reported 10-year survival rates of 72\% [2] and 78\% [21] (Tables 1, 2).

\section{Radiation Therapy}

The optimal treatment of most patients with SP is moderate-dose RT. Approximately 40-50 Gy are administered once daily at 1.8-2.0 Gy per fraction in a continuous course. For RT planning, MRI is extremely useful to delineate the gross tumor volume (GTV), both within and beyond the bone. This is important for the head and neck areas (e.g., paranasal sinuses), where inflammatory changes may be difficult to distinguish from tumor on CT scan. The FDG-PET could be used to delineate the tumor and response to treatment; however, the role of FDG-PET in defining tumor extent to assist in RT planning requires further investigation [12].

Clinical target volume (CTV) should encompass probable routes of microscopic spread, recognizing that barriers to the extension of local disease will vary according to the anatomical location, as will the morbidity of treating adjacent normal tissues. Jyothirmayi et al. [25] reported that, among 30 patients with SP treated with RT that encompassed only the tumor with a margin, no marginal recurrence was seen. Prophylactic regional lymph node coverage is not necessary in SPB, as the regional nodal failure rate is low after local RT without intentional coverage of adjacent nodes $[4,23,25,26]$. For EMP, nodal involvement at presentation is observed in only $10-20 \%$ of the patients, and planning target volume (PTV) does not justify covering the regional lymph nodes [2]. Strojan et al. [3], in a series of 26 patients, concluded that prophylactic nodal radiation is probably unnecessary.
Planning target volume (PTV) should account for setup variation from day to day and organ motion issues, typically adding 5-10 $\mathrm{mm}$ to the CTV depending on the immobilization technique employed. Although parallel-opposed fields are commonly adequate to encompass disease, CT-based planning and the use of conformal or intensity-modulated RT (IMRT) techniques should be used when needed to treat the PTV adjacent to critical structures. This is especially important in extramedullary disease involving the head and neck areas where avoidance of the eyes, optic nerves, and salivary glands is desirable to minimize morbidity.

Solitary plasmacytomas are radiation-sensitive tumors. Most studies documented response rates of $85 \%$ or more for patients treated with 35 Gy or more. Some investigators reported better local control following doses of 45 Gy or more $[6,27]$, while others have found no indication of improved outcome with higher doses $[2,26]$. A dose-response analysis of 81 patients by Mendenhall et al. [2,25] led to a recommendation of a minimum dose of $40 \mathrm{~Gy}$ for both bone and extramedullary SP. In their study, a total dose of 40 Gy or more gave a local failure rate of $6 \%$, compared with a suboptimal $31 \%$ for lower doses [24]. Therefore, the standard practice is to administer a dose of 40-45 Gy or even higher for bulky tumors. However, in one of the largest studies $(n=258)$, there was no evidence of improved local control with RT doses increasing from 30-50 Gy, even for the subset of patients with tumors larger than 4 $\mathrm{cm}$ [2]. In fact, there was a worse local control rate for the group receiving a total dose of 50 Gy or more, although this was not statistically significant [2]. These findings should be interpreted carefully because in these retrospective studies, dose-response rates are typically confounded by selection bias, as high doses are to be prescribed to larger tumors with worse prognosis.

Table 1. Solitary plasmacytoma of bone

\begin{tabular}{lccccc}
\hline Author & $\mathbf{n}$ & LC & MMFS & DFS & OS \\
\hline Tsang RW [4] & 32 & $78 \%(8 \mathrm{yrs})$ & $36 \%(8 \mathrm{yrs})$ & - & - \\
Knobel D [15] & 206 & $79 \%(10 \mathrm{yrs})$ & $51 \%(10 \mathrm{yrs})$ & $46 \%(10 \mathrm{yrs})$ & $50 \%(10 \mathrm{yrs})$ \\
Wilder RB [16] & 60 & $90 \%(10 \mathrm{yrs})$ & $38 \%(10 \mathrm{yrs})$ & $57 \%(10 \mathrm{yrs})$ & $59 \%(10 \mathrm{yrs})$ \\
KilçוksIz S [17] & 57 & $94 \%(10 \mathrm{yrs})$ & Median $4.1 \mathrm{yrs}$ & Median 3.2 yrs & $68 \%(10 \mathrm{yrs})$ \\
Bolek TW [18] & 27 & $96 \%$ & $0 \%(15 \mathrm{yrs})$ & - & $23 \%(15 \mathrm{yrs})$ \\
\hline
\end{tabular}

Note: Time interval (in parentheses) indicates follow-up point at which the outcome was observed

LC: Local control; DFS: Disease-free survival; MMFS: Multiple myeloma-free survival; OS: Overall survival

Table 2. Extramedullary plasmacytoma

\begin{tabular}{lccccc}
\hline Author & $\mathbf{n}$ & LC & MMFS & DFS & OS \\
\hline Özşahin M [2] & 52 & $74 \%$ & $36 \%(10 \mathrm{yrs})$ & $55 \%(10 \mathrm{yrs})$ & $72 \%(10 \mathrm{yrs})$ \\
Strojan P [3] & 26 & $87 \%(10 \mathrm{yrs})$ & $92 \%(10 \mathrm{yrs})$ & $87 \%(10 \mathrm{yrs})$ & $61 \%(10 \mathrm{yrs})$ \\
\hline Tsang RW [4] & 14 & $93 \%(8 \mathrm{yrs})$ & $84 \%(8 \mathrm{yrs})$ & - & - \\
Tournier-Rangeard L [6] & 17 & $88.2 \%(10 \mathrm{yrs})$ & $63.8 \%(10 \mathrm{yrs})$ & $53.5 \%(10 \mathrm{yrs})$ & $63.4 \%(10 \mathrm{yrs})$ \\
Liebross RH [8] & 22 & $95 \%$ & $56 \%(5 \mathrm{yrs})$ & $78 \%(5 \mathrm{yrs})$ & - \\
Kilçıksız S [17] & 23 & $95 \%(10 \mathrm{yrs})$ & Median $7.4 \mathrm{yrs}$ & Median $7.4 \mathrm{yrs}$ & $89 \%(10 \mathrm{yrs})$ \\
Bolek TW [18] & 10 & $100 \%$ & $67 \%(15 \mathrm{yrs})$ & - & $80 \%(15 \mathrm{yrs})$ \\
\hline
\end{tabular}

Note: Time interval (in parentheses) indicates follow-up point at which the outcome was observed

LC: Local control; DFS: Disease-free survival; MMFS: Multiple myeloma-free survival; OS: Overall survival 
Durable local control is obtained in $85 \%$ of small tumors $(<5 \mathrm{~cm})$ with 35-40 Gy, and there is little evidence that higher doses are necessary, regardless of bone or extramedullary locations. However, SP of $>5 \mathrm{~cm}$ have worse local control $[2,4]$, and doses of 45-50 Gy are recommended in these larger tumors. Despite this, one should be aware that the quality of evidence supporting the use of higher RT doses is limited, and local recurrences are still infrequently observed even after doses exceeding 50 Gy [2,4]. Özşahin et al. [2] recommended a minimum dose of 45 Gy should be prescribed even for patients who undergo surgery. Conversely, in the event of a bulky tumor and no surgery, a dose to the CTV could be even higher than 45 Gy, possibly 50 Gy, to improve local control.

\section{Prognostic Factors Affecting the Outcome}

Advanced age is clearly associated with poor survival [2]. Similarly, higher risk of progression to MM was observed in the elderly in some studies $[4,19,28]$ but not confirmed by others [2,29-32]. A bony presentation was consistently demonstrated to have a higher risk of $\mathrm{MM}$ progression with a 10-year rate of $76 \%$, compared with an extramedullary presentation, in which the 10-year MM rate was 36\% [2]. Subclinical osteopenia [33] or abnormal MRI scan of the spine $[10,34,35]$ reflects presence of occult disease, and predicts rapid progression to systemic myeloma. A suppression of the normal immunoglobulin classes, also known as immunoparesis, correlates with a higher risk of progressing to MM $[33,36]$. M-protein levels are reported to be a predictive factor of occult disseminated disease, and patients showing persistent M-protein levels for more than one year after RT are prone to progress to MM $[8,16,37]$. Anaplastic plasmacytomas (those with a higher histologic grade) [26] and tumors with a high level of angiogenesis [9] are associated with poorer outcomes.

Tumor size is reported to be an important prognostic factor in terms of local control. According to Tsang et al. [4], in tumors smaller than $5 \mathrm{~cm}$, a high level of local control was achieved with $35 \mathrm{~Gy}$, whereas those $5 \mathrm{~cm}$ or larger had a local failure rate of $58 \%$. The importance of tumor bulk is also supported by others $[2,30,31]$.

\section{Follow-Up}

Since there is a significant risk of recurrence of disease as $\mathrm{MM}$, repeat measurements of M-protein may detect the onset of systemic disease prior to the development of symptoms [16]. Complete blood counts should be taken periodically to evaluate bone marrow function. The occurrence of new bone pain requires further investigations, including imaging as appropriate.

\section{Conclusion}

Solitary plasmacytoma is a relatively uncommon malignancy that frequently presents in the vertebrae (SPB) or head and neck (EMP). Most patients are treated with moderate-dose RT. Some investigators reported better local control following doses of 45 Gy or more [6,27], while others have found no indication of improved outcome using higher doses [2,26]; a subset of patients may require surgical intervention. At the present time, adjuvant chemotherapy is not indicated. The likelihood of local control after treatment is high. The most common pattern of relapse is systemic myeloma progression, which is more likely to occur after treatment for SPB compared with EMP. Strategies to improve outcome will be related to improved management of $\mathrm{MM}$ in the subset of patients who develop systemic relapse. Future prospective studies should focus on the use of adjuvant chemotherapy and/or novel therapeutic agents, i.e., proteosome inhibitors.

\section{Conflict of interest}

No author of this paper has a conflict of interest, including specific financial interests, relationships, and/or affiliations relevant to the subject matter or materials included in this manuscript.

\section{References}

1. Durie BG, Kyle RA, Belch A, Bensinger W, Blade J, Boccadoro M, Child JA, Comenzo R, Djulbegovic B, Fantl D, Gahrton G, Harousseau JL, Hungria V, Joshua D, Ludwig H, Mehta J, Morales AR, Morgan G, Nouel A, Oken M, Powles R, Roodman D, San Miguel J, Shimizu K, Singhal S, Sirohi B, Sonneveld P, Tricot G, Van Ness B. Myeloma management guidelines: a consensus report from the Scientific Advisors of the International Myeloma Foundation. Hematol J 2003;4:379-98.

2. Ozsahin M, Tsang RW, Poortmans P, Belkacemi $Y$, Bolla M, Oner Dincbas F, Landmann C, Castelain B, Buijsen J, Curschmann J, Kadish SP, Kowalczyk A, Anacak Y, Hammer J, Nguyen TD, Studer G, Cooper R, Sengöz M, Scandolaro L, Zouhair A. Outcomes and patterns of failure in solitary plasmacytoma: A multicenter Rare Cancer Network study of 258 patients. Int J Radiat Oncol Biol Phys 2006;64:210-7.

3. Strojan P, Soba E, Lamovec J, Munda A. Extramedullary plasmacytoma: clinical and histopathologic study. Int J Radiat Oncol Biol Phys 2002;53:692-701.

4. Tsang RW, Gospodarowicz MK, Pintilie M, Bezjak A, Wells W, Hodgson DC, Stewart AK. Solitary plasmacytoma treated with radiotherapy: impact of tumor size on outcome. Int J Radiat Oncol Biol Phys 2001;50:113-20.

5. Alexiou C, Kau RJ, Dietzfelbinger H, Kremer M, Spiess JC, Schratzenstaller B, Arnold W. Extramedullary plasmacytoma: tumor occurrence and therapeutic concepts. Cancer 1999;85:2305-14.

6. Tournier-Rangeard L, Lapeyre M, Graff-Caillaud P, Mege A, Dolivet G, Toussaint B, Charra-Brunaud C, Hofstetter S, Marchal C, Peifert D. Radiotherapy for solitary extramedullary plasmacytoma in the head-and-neck region: A dose greater than 45 Gy to the target volume improves the local control. Int J Radiat Oncol Biol Phys 2006;64:1013-7.

7. Hussong JW, Perkins SL, Schnitzer B, Hargreaves H, Frizzera G. Extramedullary plasmacytoma: a form of marginal zone cell lymphoma? Am J Clin Pathol 1999;111:111-6.

8. Van de Berg BC, Lecouvet FE, Michaux L, Labaisse M, Malghem J, Jamart J, Maldague BE, Ferrant A, Michaux JL. Stage I multiple myeloma: value of MR imaging of the bone marrow in the determination of prognosis. Radiology 1996;201:243-6.

9. Kumar S, Fonseca R, Dispenzieri A, Lacy MQ, Lust JA, Wellik L, Witzig TE, Gertz MA, Kyle RA, Greipp PR, Rajkumar SV. Prognostic value of angiogenesis in solitary bone plasmacytoma. Blood 2003;101:1715-7. 
10. Liebross RH, Ha CS, Cox JD, Weber D, Delasalle K, Alexanian R. Solitary bone plasmacytoma: outcome and prognostic factors following radiotherapy. Int $J$ Radiat Oncol Biol Phys 1998;41:1063-7.mination of prognosis. Radiology 1996;201:243-6.

11. He Mx, Zhu MH, Zhang YM, Fu qg, Wu LL. Solitary plasmacytoma of spine: a clinical, radiologic and pathologic study of 13 cases. Zhonghua Bing Li Xue Za Zhi 2009;38:307-11.

12. Kim PJ, Hicks RJ, Wirth A, Ryan G, Seymour JF, Prince HM, Mac Manus MP.Impact of 18F-fluorodeoxyglucose positron emission tomography before and after definitive radiation therapy in patients with apparently solitary plasmacytoma. Int J Radiat Oncol Biol Phys 2009;74:740-6.

13. Schirrmeister H, Buck AK, Bergmann L, Reske SN, Bommer M. Positron emission tomography (PET) for staging of solitary plasmacytoma. Cancer Biother Radiopharm 2003;18:841-5.

14. Soutar R, Lucraft H, Jackson G, Reece A, Bird J, Low E, Samson D. Guidelines on the diagnosis and management of solitary plasmacytoma of bone and solitary extramedullary plasmacytoma. Clin Oncol 2004;16:405-13.

15. Knobel D, Zouhair A, Tsang RW, Poortmans P, Belkacemi Y, Bolla M, Oner FD, Landmann C, Castelain B, Ozsahin MI. Prognostic factors in solitary plasmacytoma of the bone: a multicenter Rare Cancer Network study. BMC Cancer 2006;6:118.

16. Wilder RB, Ha CS, Cox JD, Weber D, Delasalle K, Alexanian R. Persistence of myeloma protein for more than one year after radiotherapy is an adverse prognostic factor in solitary plasmacytoma of bone. Cancer 2002;94:1532-7.

17. Kilciksiz S, Celik OK, Pak Y, Demiral AN, Pehlivan M, Orhan O, Tokatli F, Agaoglu F, Zincircioglu B, Atasoy BM, Ozseker N, Yersal $\mathrm{O}$, Niang $U$, Haydaroglu A. Clinical and prognostic features of plasmacytomas: a multicenter study of Turkish Oncology Group-Sarcoma Working Party. Am J Hematol 2008;83:702-7.

18. Bolek TW, Marcus RB, Mendenhall NP. Solitary plasmacytoma of bone and soft tissue. Int J Radiat Oncol Biol Phys 1996;36:329-33.

19. Bataille R, Sany J. Solitary myeloma: clinical and prognostic features of a review of 114 cases. Cancer 1981;48:845-51.

20. Aviles A, Huerta-Guzman J, Delgado S, Fernandez A, DiazMaqueo JC. Improved outcome in solitary bone plasmacytomata with combined therapy. Hematol Oncol 1996;14:111-7.

21. Galieni P, Cavo M, Pulsoni A, Avvisati G, Bigazzi C, Neri S, Caliceti U, Benni M, Ronconi S, Lauria F. Clinical outcome of extramedullary plasmacytoma. Haematologica 2000;85:47-51.

22. Chao MW, Gibbs P, Wirth A, Quong G, Guiney MJ, Liew KH. Radiotherapy in the management of solitary extramedullary plasmacytoma. Intern Med J 2005;35:211-5.

23. Liebross RH, Ha CS, Cox JD, Weber D, Delasalle K, Alexanian R. Clinical course of solitary extramedullary plasmacytoma. Radiother Oncol 1999;52:245-9.
24. Mendenhall CM, Thar TL, Million RR. Solitary plasmacytoma of bone and soft tissue. Int $J$ Radiat Oncol Biol Phys 1980;6:1497-501.

25. Susnerwala SS, Shanks JH, Banerjee SS, Scarffe JH, Farrington WT, Slevin NJ. Extramedullary plasmacytoma of the head and neck region: clinicopathological correlation in 25 cases. Br J Cancer 1997;75:921-7.

26. Jyothirmayi R, Gangadharan VP, Nair MK, Rajan B. Radiotherapy in the treatment of solitary plasmacytoma. $\mathrm{Br} J$ Radiol 1997;70:511-6.

27. Frassica DA, Frassica FJ, Schray MF, Sim FH, Kyle RA. Solitary plasmacytoma of bone: Mayo Clinic experience. Int J Radiat Oncol Biol Phys 1989;16:43-8.

28. Chak LY, Cox RS, Bostwick DG, Hoppe RT. Solitary plasmacytoma of bone: treatment, progression, and survival. J Clin Oncol 1987;5:1811-5.

29. Bolek TW, Marcus RB, Mendenhall NP. Solitary plasmacytoma of bone and soft tissue. Int J Radiat Oncol Biol Phys 1996;36:329-33.

30. Holland J, Trenkner DA, Wasserman TH, Fineberg B. Plasmacytoma: treatment results and conversion to myeloma. Cancer 1992;69:1513-7.

31. Mayr NA, Wen BC, Hussey DH, Burns CP, Staples JJ, Doornbos JF, Vigliotti AP. The role of radiation therapy in the treatment of solitary plasmacytomas. Radiother Oncol 1990;17:293-303.

32. Shih LY, Dunn P, Leung WM, Chen WJ, Wang PN. Localised plasmacytomas in Taiwan: comparison between extramedullary plasmacytoma and solitary plasmacytoma of bone. Br $\mathrm{J}$ Cancer 1995 71:128-33.

33. Galieni P, Cavo M, Avvisati G, Pulsoni A, Falbo R, Bonelli MA, Russo D, Petrucci MT, Bucalossi A, Tura S. Solitary plasmacytoma of bone and extramedullary plasmacytoma: two different entities? Ann Oncol 1995;6:687-91.

34. Moulopoulos LA, Dimopoulos MA, Smith TL, Weber DM, Delasalle KB, Libshitz HI, Alexanian R. Prognostic significance of magnetic resonance imaging in patients with asymptomatic multiple myeloma. J Clin Oncol 1995;13:251-6.

35. Mariette X, Zagdanski AM, Guermazi A, Bergot C, Arnould A, Frija J, Brouet JC, Fermand JP. Prognostic value of vertebral lesions detected by magnetic resonance imaging in patients with stage I multiple myeloma. Br J Haematol 1999;104:723-9.

36. Jackson A, Scarffe JH. Prognostic significance of osteopenia and immunoparesis at presentation in patients with solitary myeloma of bone. Eur J Cancer 1999;26:363-71.

37. Dingli D, Kyle RA, Rajkumar SV, Nowakowski GS, Larson DR, Bida JP, Gertz MA, Therneau TM, Melton LJ 3rd, Dispenzieri A, Katzmann JA. Immunoglobulin free light chains and solitary plasmacytoma of bone. Blood 2006;108:1979-83. 